\title{
Study the Effect of Diameter and Depth of Parabolic Dish Collector on the Concentration Ratio and Temperature Amount of Solar Tower Receiver
}

\author{
Sattar Aljabair \\ Laith Jaafer Habeeb \\ Ameer mohammed ali \\ Mechanical Engineering Department, University of Technology, Baghdad-Iraq \\ drsattar2017@gmail.com laithhabeeb1974@gmail.com ameeralmayahi@yahoo.com
}

\begin{tabular}{|l|l|l|}
\hline Submission date:- 13/11/2018 & Acceptance date:- 3/1/2019 & Publication date:- 24/1/2019 \\
\hline
\end{tabular}

\begin{abstract}
This work introduces three models of parabolic dish collectors with different dimension to study the effect of change diameter and depth of the dish on the position of focus point and concentration ratio and the temperature of outlet hot water or steam by using different receivers. The present work deals with a new system consists of dish and receiver to produce hot water and steam from solar energy. The parabolic dish solar collector fabricated from iron with different dimension the first model with diameter $(82 \mathrm{~cm})$ and depth $(6 \mathrm{~cm})$, this gives focus length $(70 \mathrm{~cm})$ and Concentration ratio $(25.6)$. The second model with a diameter $(100 \mathrm{~cm})$ and depth $(3 \mathrm{~cm})$, this give focus length $(208 \mathrm{~cm})$ and concentration ratio $(15)$. The third model with a diameter $(150 \mathrm{~cm})$ and depth $(12 \mathrm{~cm})$, This give focus length $(100 \mathrm{~cm})$ and concentration ratio (399) and the front side covered by nickel sheet metal to focus the solar radiation upon the receiver for all models . Three different shapes of receiver tanks used with the third model ; namely case one which used rectangular receiver tank $(100 \times 50 \times 5) \mathrm{cm}^{3}$ filled with 25 liter of water. Case two used helical copper coil $(12.5 \mathrm{~mm} \times 3 \mathrm{~m})$ inside aluminum cylindrical vessel $(0.2 \mathrm{~m} \times 0.6 \mathrm{~m})$. Case three used radiator heat exchanger receiver tank $(37 \times 47 \times 4) \mathrm{cm}^{3}$ filled with 3 liter of water. Use low cost and available materials to manufacture the experimental part. The dish, used as part of the solar reflector, covered by several strips of nickel sheet metal. When the parabolic dish collector was operational, the temperature of water was $60{ }^{\circ} \mathrm{C}$ in rectangular receiver tank, $75{ }^{\circ} \mathrm{C}$ within the copper coil and $125{ }^{\circ} \mathrm{C}$ in radiator device receiver. For rectangular receiver tank, hot water obtained within time $(2 \mathrm{~h})$, for copper coil receiver tank, hot water obtained within time $(30 \mathrm{~min})$ and for radiator heat exchanger receiver, steam obtained within time (20 $\min )$.
\end{abstract}

Keywords: Heat transfer, Solar radiation, Dish collector, Receiver tank, Radiator heat exchanger 


\title{
Nomenclature
}

\author{
Aa Aperture area $\mathrm{m}^{2}$ \\ Ar Receiver area $\mathrm{m}^{2}$ \\ CR Concentration ratio \\ $\mathrm{Cp} \quad$ Specific heat at constant pressure $\mathrm{kj} / \mathrm{kg}$ \\ Da Diameter of dish $m$ \\ $\mathrm{F}$ Focus point $\mathrm{m}$ \\ rr Edge radius $m$ \\ $\mathrm{Rr}$ Receptor radius $\mathrm{m}$ \\ $\delta$ Sun's declination angle degree \\ $\theta \mathrm{i}$ Incidence angle of solar radiation degree \\ $\theta \mathrm{r}$ Angle of reflection degree \\ $\theta \mathrm{z}$ Zenith angle degree \\ $\varnothing \quad$ Rim angle degree \\ $\alpha_{s}$ Solar altitude angle degree \\ $\gamma_{\mathrm{s}}$ Solar azimuth angle degree \\ $\rho$ Coefficient of reflectivity \\ $\tau$ Transmittance \\ $\gamma$ Absorptivity
}

\section{Nomenclature}

The engine driven by solar energy for thermal to electricity conversion is one of the most promising solution of renewable technologies to reduce the dependency from fossil fuels. Unfortunately, the lack of data about the performance and some operational parameters of this technology limited its detailed characterization and sizing. Solar energy technology has an important role to play in the present energy and environment crises. Solar concentrator technology has good potential for various applications, including power generation and process heating applications. Scope of research and development is ample in this area, as very little work done on it. Today, our world is facing an ongoing economic crisis due to highenergy prices and increased demand for fossil or conventional fuels (oil, gas and coal). In addition, the planet exposed to environmental pollution due to the emission of carbon dioxide and other gases, which led to heat exhaustion, high temperature, acid rain, melting of snow, submerging arable land, and depletion of other areas leading to desertification, which result in increased usage of the sources of renewable energy. The foremost possible candidate to supply the bulk of renewable energy is that the assortment of solar power. It is out there, low price and clean energy that effective to renewable electricity technologies. This can be as a result of it's simply to produce, once transported as energy from the star belt of world (such as Iraq) to the population centers [1]. Parabolic dishes have several important advantages: 1 . because they are always pointing to the sun, they are the most efficient of all collector systems. 2 . They typically have a concentration ratio in the range of 600-2000, and thus are highly efficient a thermal-energy absorption and power conversion systems. 3. They have modular collector and receiver units that can either function independently or as part of a larger system of dishes [2].

The researcher gave a paper on solar thermal collectors and applications and he presented an introduction into the uses of solar energy followed by a description of the various types of collectors including flat-plate, compound parabolic, evacuated tube, parabolic trough, Fresnel lens, parabolic dish and heliostat field collectors. This followed by an optical, thermal and thermodynamic analysis of the collectors and a description of the methods used to evaluate their performance. Typical applications of the various types of collectors presented in order to show the extent of their applicability [3]. Another person had designed, made and tested a parabolic dish collector system, a black absorbent material focused heat from the radiation that fastened within the reflector focus purpose. The water was converted to steam as a result of it heated to awfully warmth. To tilt the parabolic dish reflector to completely different angles, it fastened on a hinged frame supported with a slotted lever, therefore the radiation forever directed to the collector at 
completely different periods of the day. In the sunny days, the results of check gave temperature on top of $(200 \mathrm{oC})$ [4]. In another paper, the researcher made and developed a replacement style approach for a solar concentrating parabolic dish. From skinny flat metal petals with extremely reflective surface, the mirror of dish shaped. Hooked up to the rear surface of the mirror petals were many skinny layers, whose shapes optimized to own reflective petals kind into a parabola, once their ends force toward one another by cables or rods, the parabola system redoubled the temperature of water up to $120 \mathrm{oC} \mathrm{[5]} \mathrm{.Developed} \mathrm{a} \mathrm{new} \mathrm{design}$ of large $500 \mathrm{~m} 2$ solar parabolic concentrator with $13.4 \mathrm{~m}$ focal length and altitude-azimuth tracking . It uses 380 identical spherical mirrors of $1.17 \mathrm{~m} \times 1.17 \mathrm{~m}$, that incorporate the glass-metal laminate mirror. Optical analysis showd that operation of receivers with geometric concentration ratio of at least 200 times should be possible [6]. By anther work, the researcher carried out development and style of a parabolic dish solar heater for domestic hot water application (up to $100 \mathrm{oC}$ ), 40 liters of hot water provided by the heater a day for a family. Obtained $(52 \%-56 \%)$ thermal potency. This vary of efficiencies was over the designed worth of $(50 \%)$. The use of a linear actuator (Superjack) to track the sun eliminates the need for constant monitoring by a human operator and, thus, reduces the cost of labour. The used cylinder receiver types [7]. The thermal efficiency of a point focus parabolic dish steam generating system was calculated under varying climatic conditions. A parabolic dish collector with cylindrical receiver used for steam or hot water generation. A performance analysis done over an entire year and it was found that as the absorber temperature was increased from 150 to $200 \mathrm{oC}$, the convective heat loss coefficient was increased by about 25 to $41 \%$ [8]. A new model was proposed and developed coupling the inhomogeneous radiation flux distribution for the dish receiver with Monte Carlo ray tracing. The main disadvantages of this approach were that the computations require a long time and the geometric parameters of the cavity were invariant [9]. A performance analysis methodology was developed for a PDSC system used for heating thermic fluid for process heating application. The thermal efficiency increases and be maximum at (15-16) pm because of the direction of sun [10].The researcher deal with utilization of solar energy to produce steam, by using solar concentrated dish. The solar radiation incident upon the dish and reflected to absorbed vessel, which contain the helical coil which carrying the water. The results of this experimental work give good indication to produce steam through short time from solar in Iraq. This experimental work run in 7september/2014 at 11:00 am. Once the radiation mirrored from the reflector to the coil receiver, the temperature of the water was $38 \mathrm{oC}$ at the primary time. Step by step enhanced till all the water is modified to the steam within the a part of the coil, after that, the steam was become superheated within the remained a part of the coil, the temperature of the made steam reach up to $115.7 \mathrm{oC}$ [11]. A design and an optimization method for a solar cavity receiver with the capability of achieving high operating temperatures. By developing a thermal model for the cavity geometry, results of that study provided a prediction of the real situation and a sensitivity analysis of the cavity receiver design. The designed cylindrical receiver with insulation consists of an enclosed bottom on the back, an aperture in the front, and a helical pipe inside [12]. A $(3.25 \mathrm{~m})$ solar dish array was designed and fabricated by using (52) plane mirror. These mirrors leveled and fixed to reflect the radiation in one area (focus) and after distance (1.5 $\mathrm{m})$. In addition, it found that the heat concentration $(217.79 \mathrm{~W})$, the useful energy $(1416.125 \mathrm{~W})$ and the center efficiency were $55 \%$ at $(400-700 \mathrm{~W} / \mathrm{m} 2)$. The solar dish array was relatively suitable for solar thermal applications [13].

\section{Theoretical Analysis of the Solar Dish Concentrator}

\section{Prototype Geometry}

To calculate the parabola, a mathematical analysis performed to find the values that satisfy the design criteria, like diameter, aperture angle, and concentration ratio. The scheme used for the analysis shown in figure (1) .Table (1,2, and 3) presents the dimensions used for the design of the solar collector dish for all model. Determination of parabolic reflector's base parameters for final model [14]: 


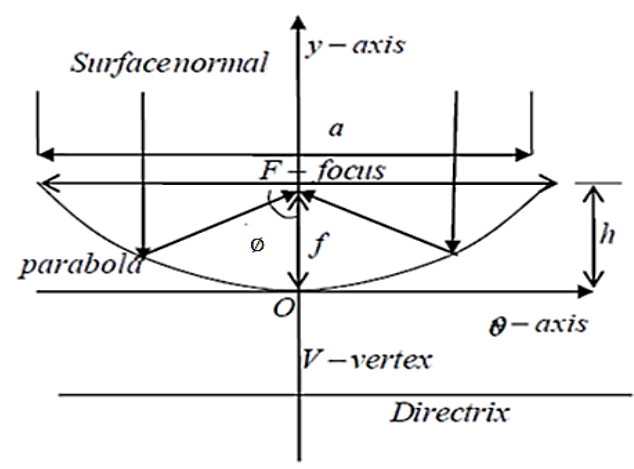

Figure (1): Geometry and dimensions of the solar collector parabolic dish.

Table (1) Dimensions of the solar collector parabolic dish for first model.

\begin{tabular}{|c|c|c|}
\hline Nomenclature & Value & Description \\
\hline $\mathrm{D}_{\mathrm{a}}$ & 82 & Diameter of aperture $(\mathrm{cm})$ \\
\hline $\mathrm{H}$ & 6 & Collector depth $(\mathrm{cm})$ \\
\hline $\mathrm{F}$ & 70 & $\begin{array}{c}\text { Focus } \\
(\mathrm{cm})\end{array}$ \\
\hline $\mathrm{a}, \mathrm{h}$ & $0.47,0.04$ & $\begin{array}{c}\text { Dimension of heat exchanger } \\
(\mathrm{m})\end{array}$ \\
\hline $\mathrm{CR}$ & 48 & Concentration ratio \\
\hline$\varnothing$ & 32.6 & Rim angle \\
\hline
\end{tabular}

Table (2) Dimensions of the solar collector parabolic dish for second model.

\begin{tabular}{|c|c|c|}
\hline Nomenclature & Value & Description \\
\hline $\mathrm{D}_{\mathrm{a}}$ & 100 & Diameter of aperture $(\mathrm{cm})$ \\
\hline $\mathrm{H}$ & 3 & Collector depth $(\mathrm{cm})$ \\
\hline $\mathrm{F}$ & 208 & $\begin{array}{c}\text { Focus } \\
(\mathrm{cm})\end{array}$ \\
\hline $\mathrm{a}, \mathrm{h}$ & $0.47,0.04$ & $\begin{array}{c}\text { Dimension of heat exchanger } \\
(\mathrm{m})\end{array}$ \\
\hline $\mathrm{CR}$ & 15 & Concentration ratio \\
\hline$\varnothing$ & 13.7 & Rim angle \\
\hline
\end{tabular}

Table (3) Dimensions of the solar collector parabolic dish for final model.

\begin{tabular}{|c|c|c|}
\hline Nomenclature & Value & Description \\
\hline $\mathrm{D}_{\mathrm{a}}$ & 1.5 & Diameter of aperture (m) \\
\hline $\mathrm{h}$ & 0.12 & Collector depth (m) \\
\hline $\mathrm{F}$ & 1 & $\begin{array}{c}\text { Focus } \\
(\mathrm{m})\end{array}$ \\
\hline $\mathrm{a}, \mathrm{h}$ & $0.47,0.04$ & $\begin{array}{l}\text { Dimension of heat exchanger } \\
(\mathrm{m})\end{array}$ \\
\hline $\mathrm{CR}$ & 399 & Concentration ratio \\
\hline$\varnothing$ & $41.1^{\circ}$ & Rim angle \\
\hline
\end{tabular}


The dimensions of a symmetrical parabola related by equation:

The focal distance is given by:

$$
f=\frac{D_{a p^{2}}}{16 h}
$$

by:

Where $\mathrm{f}=$ focal length, $\mathrm{D}_{\mathrm{ap}}=$ the rim diameter and $\mathrm{h}=$ Parabola depth. The focal distance is given

Assuming the aperture diameter to be $1.5 \mathrm{~m}$ and $0.12 \mathrm{~m}$ depth Where, $D_{a p}=$ aperture diameter, $h=$ the depth, $D_{a p}=1.5 \mathrm{~m}$ and $h=0.12$

So, $f=100 \mathrm{~cm}$

The relationship between focal length with the rim angle and aperture diameter of the parabolic dish given as (Stine, William B. Diver, Richard B. 1994):

$$
\emptyset_{\text {rim }}=\tan \left[\frac{\frac{8 f}{D a p}}{16\left(\frac{f}{D_{a p}}\right)^{2}-1}\right]
$$

Where $\emptyset_{\text {rim }}=$ Rim angel $=41.1^{\circ}$

$D_{a p}$ : dish diameter

$h:$ dish depth

$f:$ focal length

$\varnothing$ : rim angle

Another important parameter to adequately define the geometry of the solar collector parabolic dish is the edge radius (rr) or maximum distance value existing between the focal point and the paraboloid extreme. Equation (2) defines said value as the following:

$$
r_{r}=\frac{2 f}{1+\cos \varnothing}=1.14 m
$$

The concentration index is defined as the ratio between the aperture area (Aa) and the area of the receiver (Ar), as shown in equation:

$$
C_{r}=\frac{A_{a}}{A_{r}}
$$

The aperture area calculated through the following ratio:

$$
A_{a}=\frac{\pi D_{a}^{2}}{4}=1.7971 \mathrm{~m}^{2}
$$

To find the area of the receiver, it is necessary to consider the aperture angle, the dimensions of the receiver, the radius of the edge, and the angle supported by the sun seen from the earth. This last constant is because the rays from the sun are not parallel to each other, given that the sun has a finite radius. From the earth, the sun seen as a circular dish that subtends a $32^{\prime}$ or $0.53^{\circ} \alpha$ angle. From figure 2, it is known that $\mathrm{a}=0.47 \mathrm{~m}, \mathrm{c}$ is the hypotenuse formed between the focus and point $\mathrm{B}$ and $\varnothing=41.1 \mathrm{o}$. According to the aforementioned, we have:

$$
c=\frac{a}{\sin \varnothing}=0.7 \mathrm{~m}
$$

Now, point B would be equal to:

$$
b=r_{r}-c=0.44 m
$$


Figure (2) shows the geometric ratio of points $\mathrm{ABE}$ and BCA.
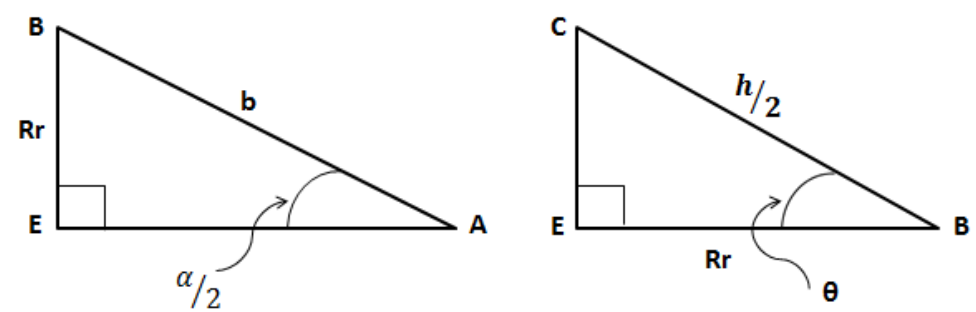

Figure (2): Geometric ratio of points $\mathrm{ABE}$ and BCE.

Where $R r$ is the receptor radius. According to the previous figure, we obtain:

$$
R r=b \sin \left(\frac{\alpha}{2}\right)=2.035 * 10^{-3}
$$

Upon observing figure (2), the following geometric ratio noted among points BCE: Where $h / 2$ is half the contact surface of the receiver cylinder. With the equation, we obtain the angle formed between $h / 2$ and $R r$.

$$
\theta=90+\frac{\alpha}{2}=106^{\circ}
$$

Also, finding half the contact surface of the receiver cylinder, as noted in equation (10):

$$
\frac{h}{2}=\frac{R r}{\cos (\theta-\varnothing)}=4.7973 * 10^{-3}
$$

The area of the receiver can be determined through equation (11):

$$
A_{r}=a h=4.5 * 10^{-3} \mathrm{~m}^{2}
$$

With values $A a, R r$ and applying equation (4), it proceed to calculate the concentration ratio of the solar collector parabolic dish:

$$
c=\frac{1.7971}{4.5 * 10^{-3}}=399
$$

The calculated concentration ratio corresponds to the maximum concentration obtained within a parabolic concentrator with a flat receptor; however, equation (12) does not consider the angular dispersion in the receptor.

Bearing in mind the angular dispersion and considering that all the specular radiation reflected is on an angular cone with $\left(0.53^{\circ}+\delta\right)$; from equation (13), it may find the value of the contact surface of the receiver cylinder considering the angular dispersion:

$$
h 1=\frac{2 R r}{\cos \left(\theta-\emptyset+\frac{\delta}{2}\right)}=0.025 \mathrm{~m}
$$

Where: $\delta$ is the specular deviation, which has a theoretical value of 3 degrees. Finding the value of h1, the actual maximum concentration ratio defined by equation (14):

$$
\text { Crmax }=\frac{A_{a}}{a h 1}=146
$$

With the actual maximum concentration ratio, it can obtain the optimal focal distance (fo), so that the highest possible concentration is achieved. By substituting, we have equation (15):

$$
C r=\frac{\frac{\pi}{4} D a 1^{2}}{a^{2}}=146=\frac{\frac{\pi}{4} D a 1^{2}}{0.47^{2}} \rightarrow D a 1=6.4 \mathrm{~m}
$$


For which, by clearing $\mathrm{f}$ in equation (1) and using the value of Da1, we have the optimal focal distance, as noted in the equation:

$$
f_{o}=\frac{6.4}{4 \tan \left(\frac{\phi}{2}\right)}=4.2 \mathrm{~m}
$$

\section{Prototype Design}

There are many stages to selecting the dimensions of the dish and tested it to reach the final suitable dimensions, which are:

Design and manufacture dish with diameter (Dap= $82 \mathrm{~cm})$, depth $(\mathrm{h}=6 \mathrm{~cm})$, focal length $(\mathrm{f}=70 \mathrm{~cm})$ and concentration ratio $(\mathrm{CR}=25.6)$ shown in figure (3a). The test was performed in $(23 / 11 / 2017)$ at 3:35 am with outlet temperature $25 \mathrm{Co}$ and max temperature of dish surface $33 \mathrm{Co}$. It found that the temperature at the front oplate is $752 \mathrm{Co}$ and behind the plate $362 \mathrm{Co}$. The plate made of steel with thickness $1 \mathrm{~mm}$.

1 Design and manufacture dish with diameter (Dap=100 cm), depth $(\mathrm{h}=3 \mathrm{~cm})$, focal length $(\mathrm{f}=208 \mathrm{~cm})$ and concentration ratio $(\mathrm{CR}=15)$ shown in figure $(3 \mathrm{~b})$. The test was performed in $(3 / 12 / 2017)$ at $12: 14$ $\mathrm{pm}$ with outlet temperature $22 \mathrm{C}^{\circ}$ and max temperature of dish surface $30 \mathrm{C}^{\circ}$. It found that the temperature at the front of plate is $150 \mathrm{C}^{\circ}$ and behind the plate is $65 \mathrm{C}^{\circ}$. The plate made of steel with thickness $1 \mathrm{~mm}$.

The purpose of this model is to get the location of the focus farther and thus manufacture a system that combines between the central tower system and parabolic dish system. However, the concentration ratio and temperature were not satisfactory.

2 Design and manufacture dish with diameter (Dap=150 cm), depth $(\mathrm{h}=12 \mathrm{~cm})$, focal length $(\mathrm{f}=100 \mathrm{~cm})$ and concentration ratio $(\mathrm{CR}=399)$ shown in figure $(3 \mathrm{c})$. The test performed in $(8 / 12 / 2017)$ at 11 am with outlet temperature $19 \mathrm{C}^{\circ}$ and max temperature of dish surface $28 \mathrm{C}^{\circ}$. It found that the temperature at the front of plate is $912 \mathrm{C}^{\circ}$ and behind the plate is $623 \mathrm{C}^{\circ}$. The plate made of steel with thickness $1 \mathrm{~mm}$.

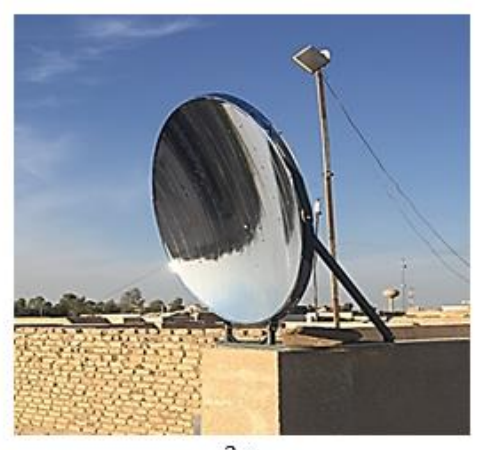

$3 a$

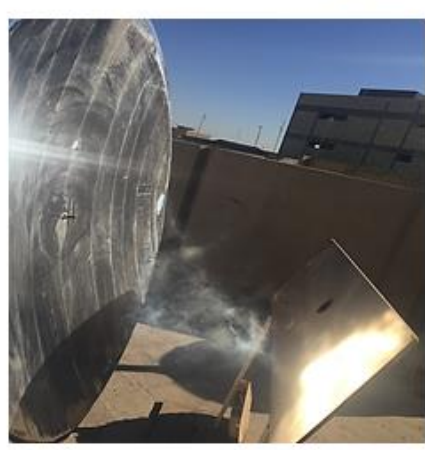

$3 c$

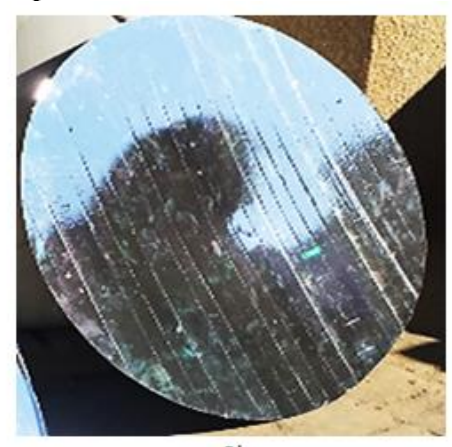

$3 b$

Figure (3a, 3b, 3c): the three model of parabolic dish. 


\section{Receiver Design}

There are three types of receivers, which designed and manufactured in practical way and test it.

\subsection{Rectangular Receiver}

The first receiver is a rectangular one with dimensions $(100 \times 50 \times 5) \mathrm{cm} 3$. The test was done at $(11: 00$ am) in $29 / 3 / 2018$ and the temperature of the surface plate was $300^{\circ} \mathrm{C}$ and the maximum temperature of water inside the receiver was $\left(60^{\circ} \mathrm{C}\right)$ and this process need $2 \mathrm{~h}$, as shown in figure (4).

Before the manufacturing, the case designed and simulated using Solidworks, ANSYS-Fluent and Static Structural Multiphysics Analysis for testing its suitability from the point of view of: heat (conduction, convection and heat flux) and structure (weight, material and deformation) respectively. Figures (5) show the 3-D graph, temperature distribution and total deformation for the whole case respectively.

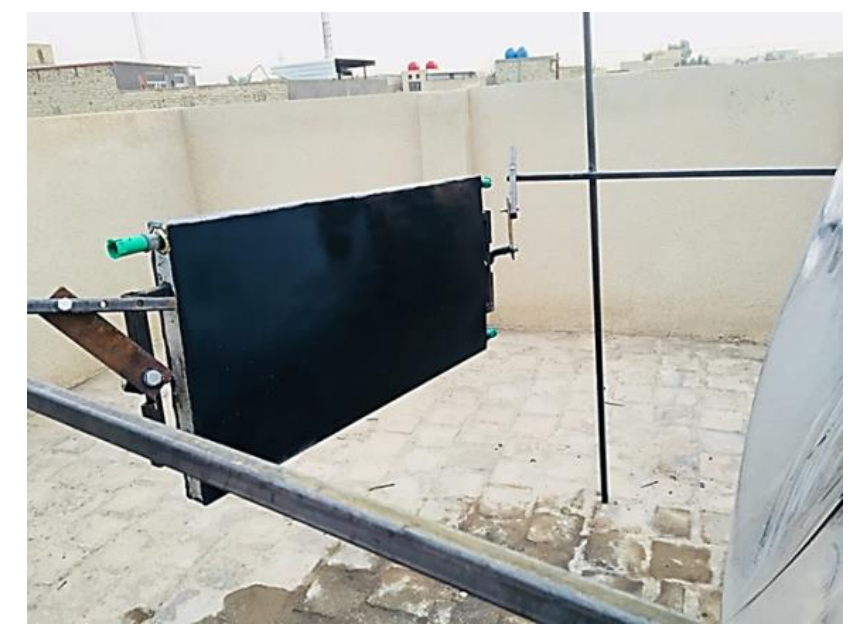

Figure (4): Photo of first type of receiver.

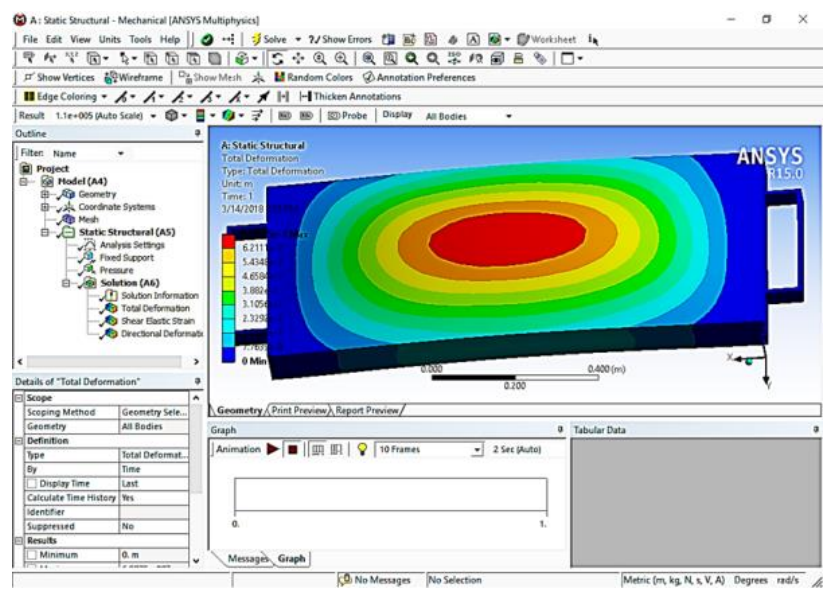

Figure (5): First type of receiver (ANSYS-Fluent).

\subsection{Helical Copper Coil Receiver}

The second take a look at, wherever mensuration of another receiver of that aluminum cylinder (20 $\mathrm{cm}$ diameter and sixty $\mathrm{cm}$ length), a spiraling copper coil (12.5 $\mathrm{mm}$ in diameter and $3 \mathrm{~m}$ long, 5 turns, 10 $\mathrm{cm}$ between 2 turn) were mounted within the cylinder as shown in figure (6). The copper coil and also the cylinder painted in black color. 


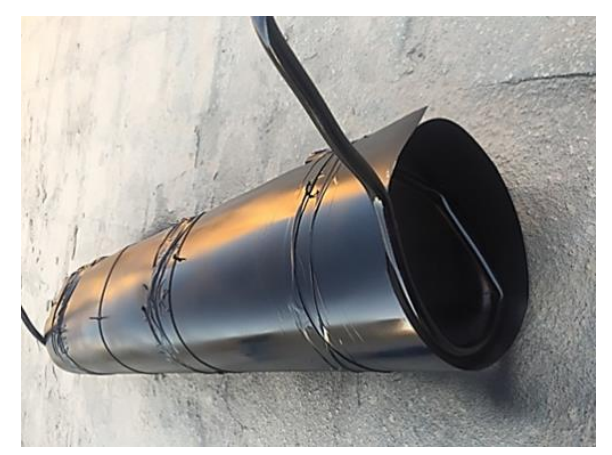

Figure (6): Photo of second type of receiver.

After fixing the receiver on the steel structure, two of the thermocouples wherever mounted. One on the recess of the spiraling coil and another one on the top of the spiraling coil. The copper coil stuffed with water (1.47 liter) by the water system pipe. This experimental work done on 10-April/2018, at 01:00 pm. once the radiation mirrored from the solar furnace to the coil receiver, the temperature of the water was 38 $\mathrm{oC}$ at the primary time. Then step by step augmented till all the water modified to hot water within the a part of the coil. The temperature of the made hot water reached $75^{\circ} \mathrm{C}$.

\subsection{Radiator Heat Exchanger Receiver}

The third model is a radiator. As known, the main function of the radiator is the cooling of the fluid passing through the tubes by air passage through the fins. Figure (7) shows the design of the radiator by using Solidworks.

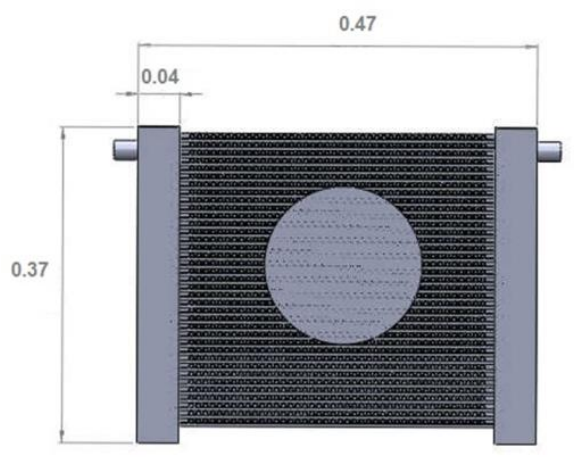

Figure (7): Final model drawing by using Solidworks.

In this case, however, the process reversed by installing an aluminum sheet on the rear side of the radiator, thus preventing the air from passing around the tubes. The radiator also installed in the center of the reflected radiation from the dish. All parts of the radiator painted black to absorb all radiation. This model made from brass with dimensions $(37 \times 47 \times 4) \mathrm{cm} 3$ and the number of tubes were 74 with dimensions $(0.01 \times 0.002) \mathrm{m} 2$, as shown in figure $(8)$. 


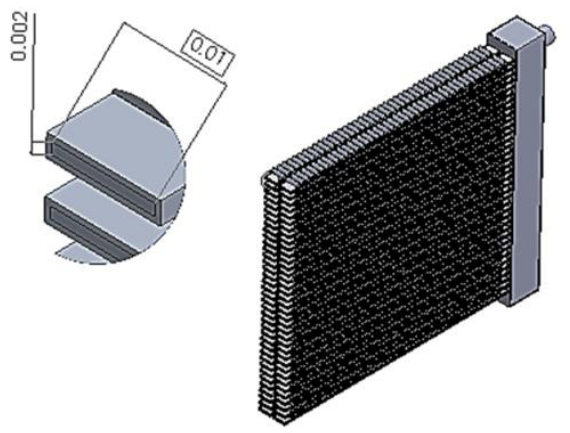

Figure (8): Dimensions of tubes in (m).

The practical model manufactured in local workshops based on a ready-made model that was cut in the required dimensions with the addition of a tank at each side to be the total capacity of (3) liter and the final cost is 60 US\$, figure (9) shows the experimental model.

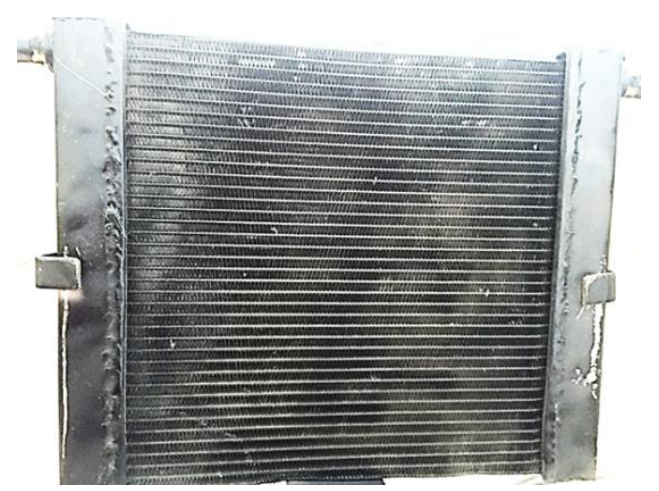

Figure (9): Photo of third type of receiver.

The reason of choosing this design is to try to obtain better results than these of previous researchers; most of them produce only hot water. In this idea, steam with high temperature and pressure were obtained in a shorter time. Therefore, a radiator that have high transfer rate been used but the mechanism reversed by stabilizing it in the front of the reflected radiation center of the dish and closing the backside to prevent airflow through the fins .

\section{Results and Discussion}

\subsection{Temperature of Rectangular Receiver}

The Table (5) explains the experimental measurements, as well as the mathematical analysis obtained from the rectangular receiver. The temperature of the hot water at the outlet of the pipe was measured for three different types of receiver periodically (every minute) using a thermocouple in the experiments related to the Parabolic Dish Collector. When the rectangular tank receiver was used, the temperature of the water rose from $35^{\circ} \mathrm{C}$ to $60{ }^{\circ} \mathrm{C}$ as shown in Figure (10). 
Table (5) Experimental results for the Parabolic Dish Collector by used rectangular receiver.

\begin{tabular}{|c|c|}
\hline Dish & Case1 (rectangular receiver ) \\
\hline Location of the plant & Iraq / Karbala \\
\hline Properties of fluid at the outlet from tank receiver & Hot water \\
\hline Dimensions of the receiver & $(100 \times 50 \times 5) \mathrm{cm}^{3}$ \\
\hline Mass of fluid inside central receiver tank & 25 liter \\
\hline Inlet temperature of water & $35^{\circ} \mathrm{C}$ \\
\hline Outlet temperature of water & $60^{\circ} \mathrm{C}$ \\
\hline Concentration ratio & 224 \\
\hline
\end{tabular}

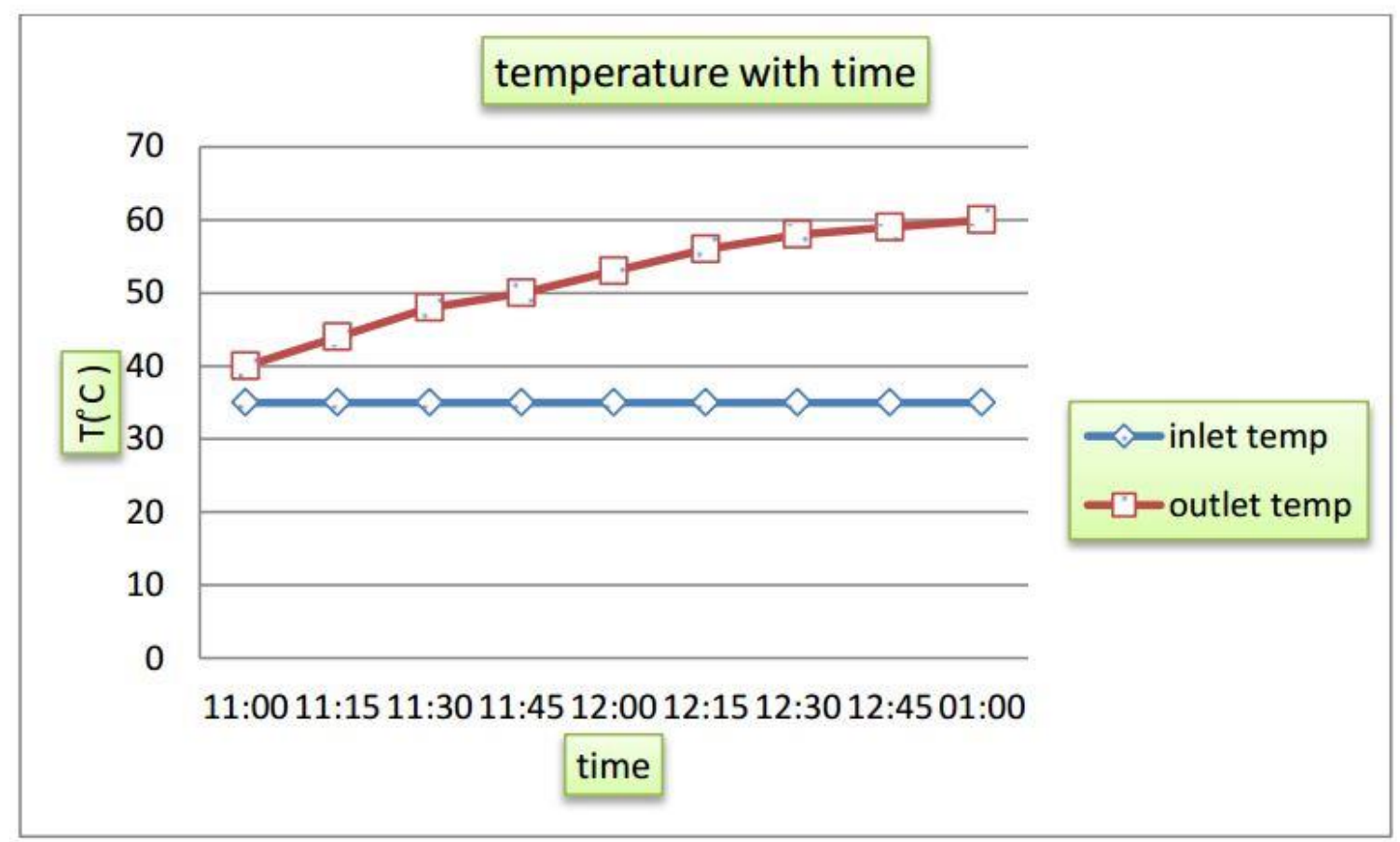

Figure (10) experimental result of rectangular receiver.

\subsection{Temperature of Helical Copper Coil Receiver}

The Table (6) explains the experimental measurements, as well as the mathematical analysis obtained from the coil copper receiver. The use of a different receiver (the helical coil receiver) for the Parabolic Dish Collector resulted in an increase of the water temperate, from $38{ }^{\circ} \mathrm{C}$ on 10 April 2018 at 1:00 PM, to $75^{\circ} \mathrm{C}$, as shown in Figure (11). For this second case, the hot water was produced in a shorter time compared with case 1 , about 30 minutes.

Table (6) Experimental results for the Parabolic Dish Collector by used Helical Copper Coil Receiver.

\begin{tabular}{|c|c|}
\hline Dish & Case2 (helical copper coil receiver) \\
\hline Location of the plant & Iraq / Karbala \\
\hline Properties of fluid at the outlet from tank receiver & Hot water \\
\hline Dimensions of the receiver & $12.5 \mathrm{~mm} \times 3 \mathrm{~m}$ Copper coil \\
\hline Mass of fluid inside central receiver tank & 1.47 liter \\
\hline Inlet temperature of water & $38^{\circ} \mathrm{C}$ \\
\hline Outlet temperature of water & $75^{\circ} \mathrm{C}$ \\
\hline Concentration ratio & 76.8 \\
\hline
\end{tabular}




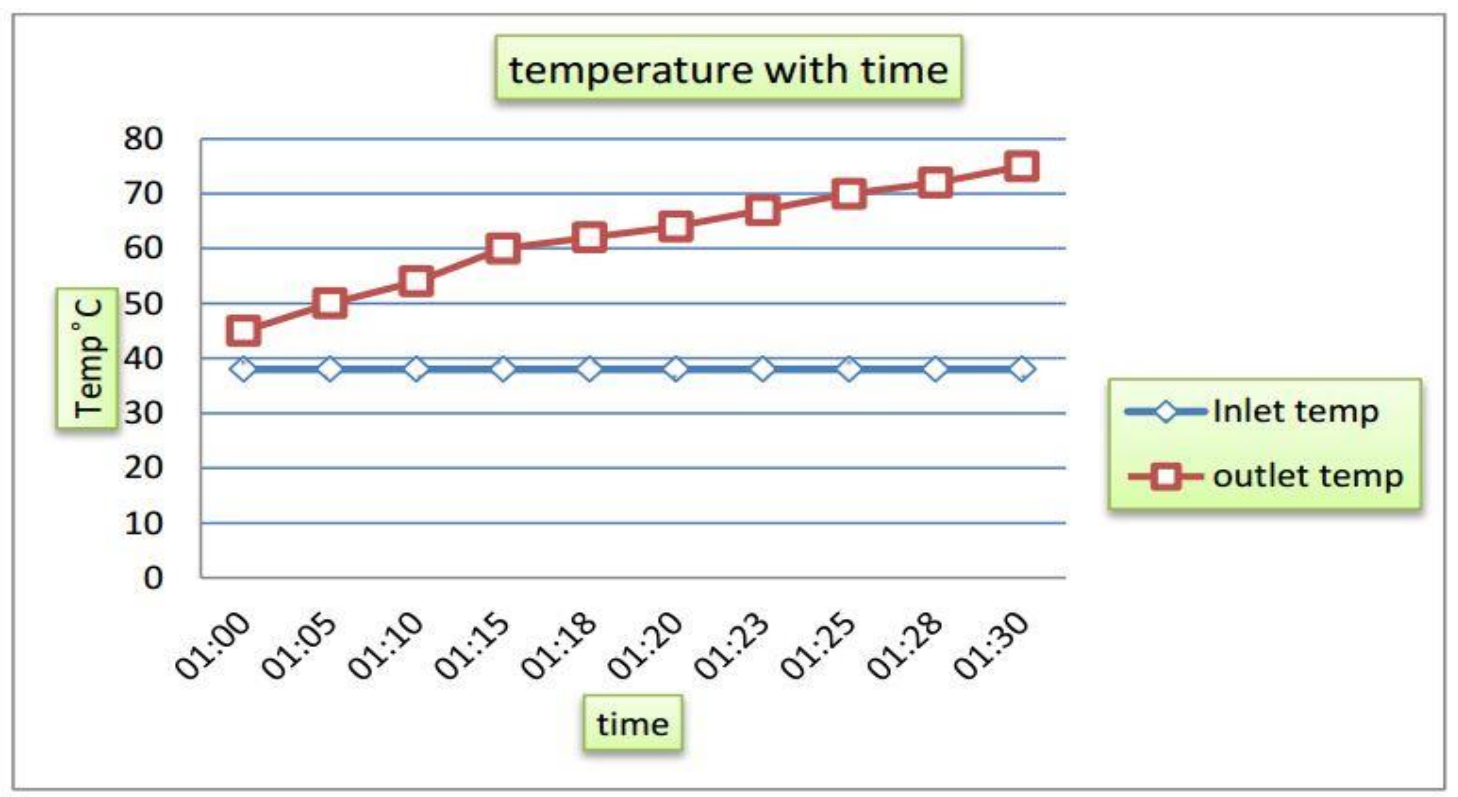

Figure (11) experimental result of Helical Copper Coil Receiver.

\subsection{Temperature of Radiator Heat Exchanger Receiver.}

The Table (7) explains the experimental measurements, as well as the mathematical analysis obtained from the radiator heat exchanger receiver.

Table (7) Experimental results for the Parabolic Dish Collector by used Radiator Heat Exchanger Receiver.

\begin{tabular}{|c|c|}
\hline Dish & Case3 (radiator heat exchanger receiver) \\
\hline Location of the plant & Iraq / Karbala \\
\hline Properties of fluid at the outlet from tank receiver & Steam \\
\hline Dimensions of the receiver & $(37 \times 47 \times 4) \mathrm{cm}$ \\
\hline Mass of fluid inside central receiver tank & 3 liter \\
\hline Inlet temperature of water & $38^{\circ} \mathrm{C}$ \\
\hline Outlet temperature of water & $125^{\circ} \mathrm{C}$ \\
\hline Concentration ratio & 399 \\
\hline
\end{tabular}

Figure (11a) shows that the input temperature remains constant during the experiment period and the temperature of the water inside the receiver increases gradually until it reaches its maximum value at $(11: 10 \mathrm{am})$ about $\left(105^{\circ} \mathrm{C}\right)$ and then decreases after opening the valve. While in figure (11b) for test 2 , the maximum temperature reached about $\left(120^{\circ} \mathrm{C}\right)$ at $(14: 17)$ for the same period of time but at different time of the day. Figures (11c) and (11d) show the difference between two experiments that performed for the same day but for different times. It was found that the temperature of the steam as well as the pressure increased after $(12: 00 \mathrm{pm})$ more than before this time. At $(11: 10 \mathrm{am})$ the outlet temperature $\left(105^{\circ} \mathrm{C}\right)$ and at $(14: 17$ $\mathrm{pm})$ the outlet temperature $\left(120^{\circ} \mathrm{C}\right)$. For the pressure inside the receiver, where in all experiments have been conducted to open the valve when the pressure increases more than $(1.4 \mathrm{bar})$ to avoid the occurrence of damage to the receiver, as happened in the first experiment, which increased pressure causing leakage of welding areas in the receiver. However, it is possible to use a control system to open and close the valve at high pressure. Figures (12a) and (12b) for May, predict the same behavior of April but with different values. After (20 minutes) the temperature increase to $\left(118{ }^{\circ} \mathrm{C}\right)$. At the same time at April its increase to $\left(115^{\circ} \mathrm{C}\right)$, figures $(12 \mathrm{c})$ and $(12 \mathrm{~d})$ illustrate the same behavior of figures (11c) and (11d) but with higher values and different times. 
Journal of University of Babylon for Engineering Sciences, Vol. (27), No. (1): 2019.

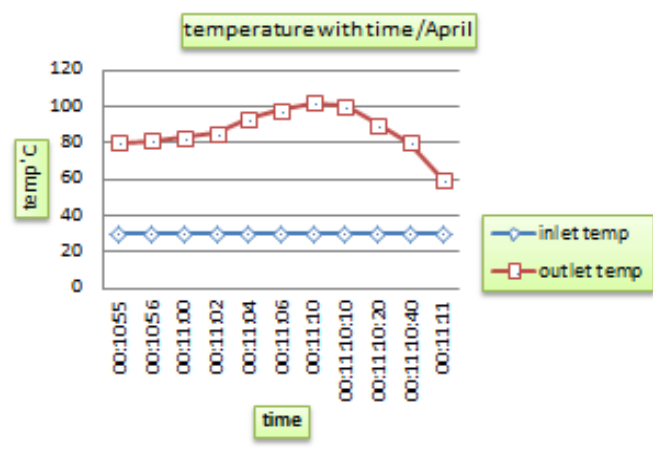

(a)

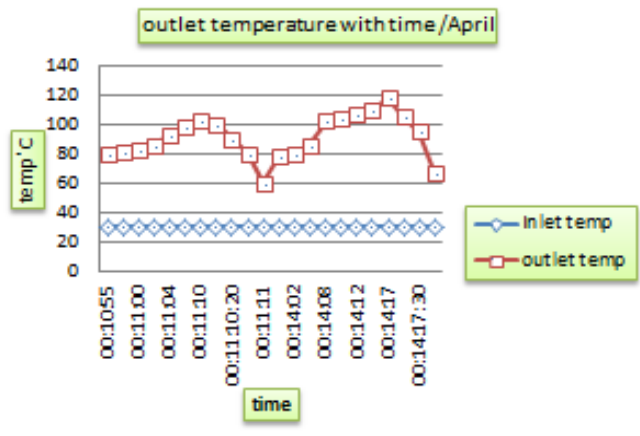

(c)

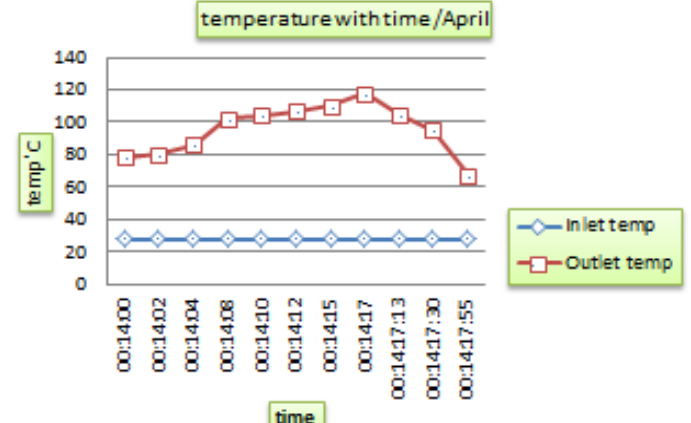

(b)

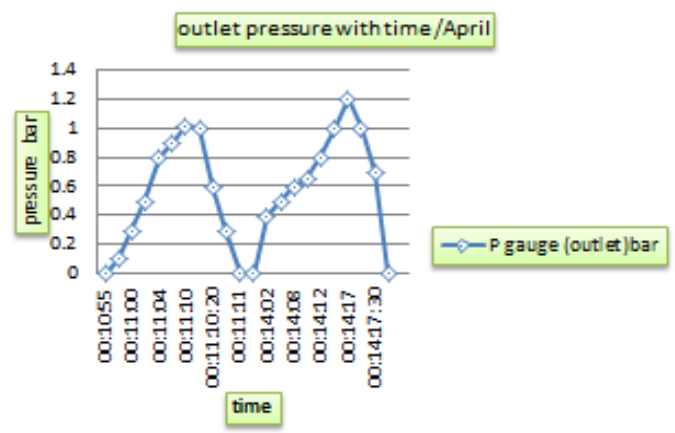

(d)

Figure (11a, 11b, 11c, 11d) experimental result of Radiator Heat Exchanger Receiver (13/April).

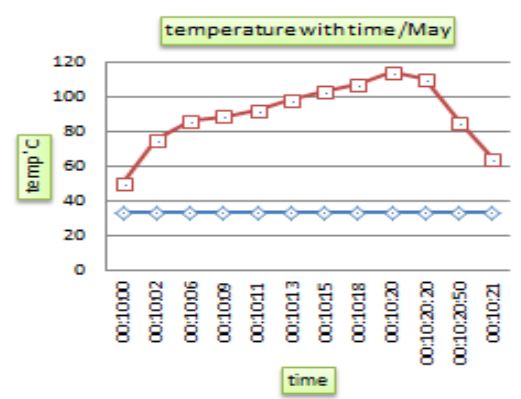

(a)

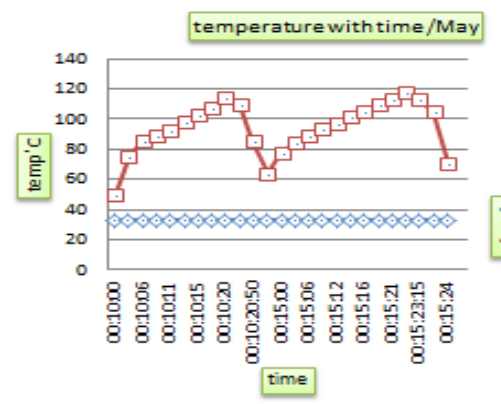

(c)

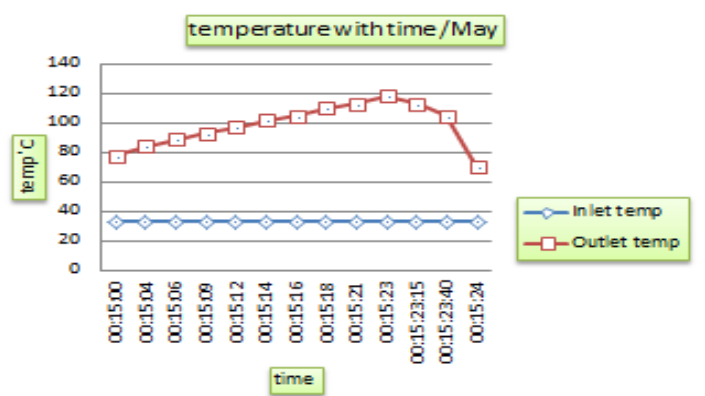

(b)

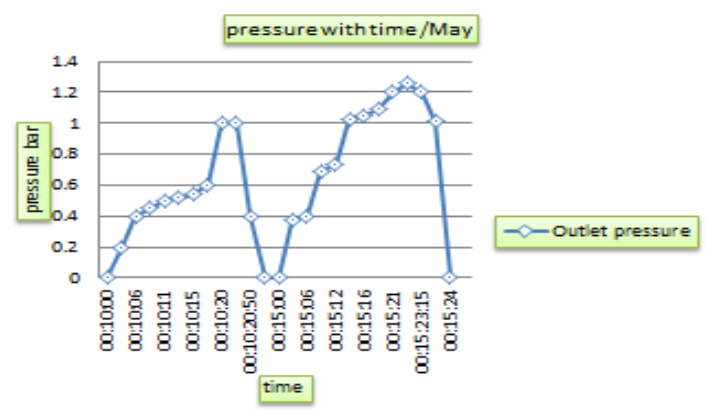

(d)

Figure (12a, 12b, 12c, 12d) experimental result of Radiator Heat Exchanger Receiver (22/May). 


\section{Conclusion}

1. The location of the focus and its distance from the dish depends on the amount of the dish diameter and the degree of its angle of inclination. However, the lower the convexity, the lower the concentration of the reflected radiation, less the radiation intensity and less the temperature.

2. The mirrors can used as reflector metal, but the problem is that they are difficult to install on the dish and easily damaged so that we used nickel sheet metal.

3. The use of the radiator receiver and its reverse function gave good results, steam obtained when the receiver closed and hot water obtained when the flow was continuous (32) liters per hour.

\section{CONFLICT OF INTERESTS.}

- There are no conflicts of interest.

\section{References}

[1] Frier, D., Cable, R. G.,"An overview and operation optimization of the Kramer Junction Solar Electric Generating System”, ISES World Congress, Jerusalem, vol. 1, pp. 241-246 1999.

[2] Ram Bhool, Pardeep Kumar, Pawan Kumar , Atul Mehla, "performance evaluation and regeneration of activated charcoal by solar parabolic dish collector" International Journal of Science, Engineering and Technology Research (IJSETR), Volume 3, Iu 5, 2014.

[3] Soteris A. Kalogirou, "Solar thermal collectors and applications", Progress in Energy and Combustion Science, vol. 30, pp. 231-295, 2004.

[4] Joshua Folaranmi, "Design, Construction and testing of a parabolic dish collector system", Journal of Power \& Engineering 210 SAND2002-0120, 2009.

[5] Lifang Li and Steven Dubowsky, "New Design approach for Solar Concentrating Parabolic Dish", Thermon Corp 34, 2010.

[6] José Zapata, Keith Lovegrove, John Pye and Greg Burgess , “ A new $500 \mathrm{~m} 2$ parabolidal dish solar concentrator", International journal Renewable Energy, vol. 85, pp. 620-626, 2011.

[7] Ibrahim Laden Mohammed, "Development and design of a parabolic dish solar water heater", Engineering and Design 238, pp. 3160-3173. 2012.

[8] G. Shiva, G. Barat, H. T. Teymour and B. Ahmad,"Thermal performance of a point-focus solar steam generating system", Annual International Conference on Mechanical Engineering, 2013.

[9] F. Cui, Y. He, Z. Cheng, Y. Li, "Study on combined heat loss of a dish receiver with quartz glass cover", Appl Energy 112 690-696. 2013.

[10] Vanita Thakkar, Ankush Doshi, Akshaykumar Rana, "Performance Analysis Methodology for Parabolic Dish Solar Concentrators for Process Heating Using Thermic Fluid", IOSR Journal of Mechanical and Civil Engineering (IOSR-JMCE) e-ISSN: 2278-1684,p-ISSN: 2320-1.334X, Volume 12, Issue 1 Ver. II (Jan- Feb., PP 101-114, 2015.

[11] Ghanim Kadhim Abdul Sada, Afreen Emad Sa'ad-Aldeen, "Experimental steady to produce steam by solar energy using solar dish concentration with copper coil receiver", International Journal of Engineering and Innovative Technology (IJEIT) Volume 4, Iu 7, 2015.

[12] Zou Chongzhe, Zhang Yanping, Quentin Falcoz, Pierre Neveu, Zhang Cheng, Shu Weicheng, Huang Shuhong, "Design and Optimization of a High-Temperature Cavity Receiver for a Solar Energy Cascade Utilization System", School of Energy and Power Engineering, Address: Room 101 Power building, HUST, Wuhan 430074, China 2016 .

[13] Mohamed M., Auatf. S. Jassim, Yaseen. H. Mahmood,"Design and fabrication of Solar dish array and study it characterization", Tikrit Journal of Pure Science 22 (11) 2017.

[14] Ahmed Mohamed, [2013] "design and testing of a solar parabolic concentrating collector", International Conference on Renewable Energies and Power Quality (ICREPQ'13) Bilbao (Spain), 2013. 


\section{دراسة تأثير قطر وعمق الطبق الثمسي على نسبة التركيز ودرجة الحرارة لمستقبل برج الطاقة الشمسية

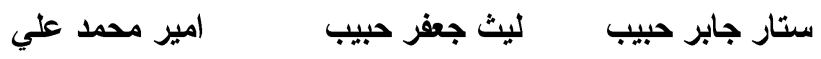 \\ قسم الهندسة الميكانيكبة، الجامعة النكنولوجية، بغداد، العراق}

ameeralmayahi@yahoo.com laithhabeeb1974@gmail.com drsattar2017@gmail.com

الخلاصة

هذا البحث ينعامل مع ثلاث نماذج من المجمعات الثمسية من نوع الطبق الثمسي وبأبعاد مختلفة لدراسة تغيير قطر الطبق

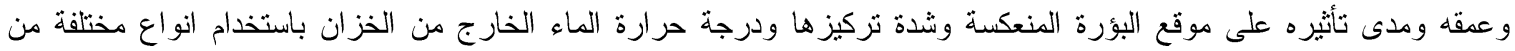
الخز انات.

هذا العمل يتعامل مع نظام جديد يتكون من طبق شمسي وخزان يستقبل الاشعة المركزة لأنتاج الماء الحار وكذلك البخار

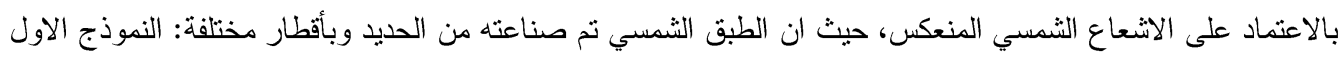

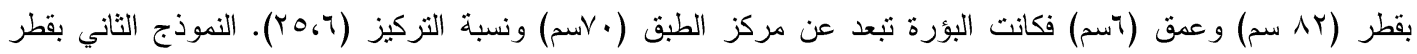

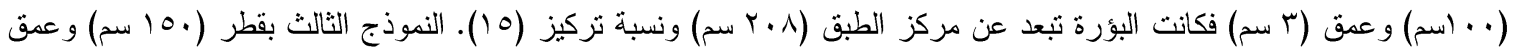

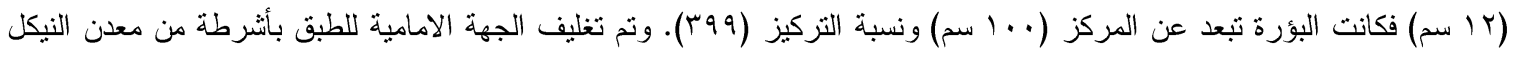
العاكس لاشعة الثمس من اجل تركيز الاشعاع الثمسي على خزان مثبت بمركز بؤرة الاثعة المنعكسة من الطبق.

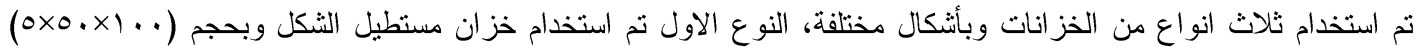

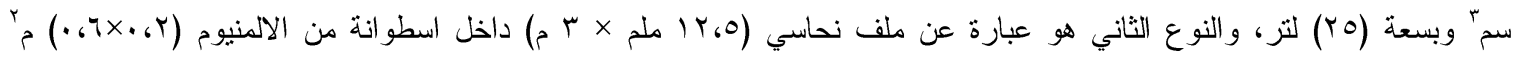

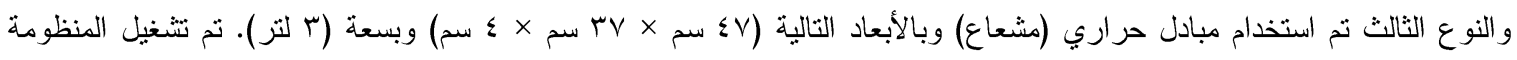

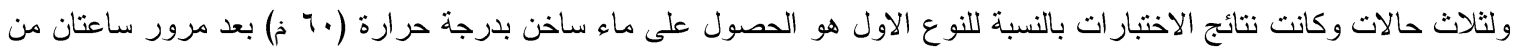

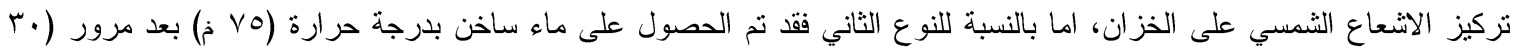

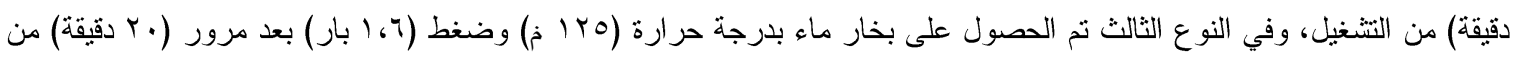
التتغيل.

الكلمات الداله: انتقال الحر ارة، الاشعاع الثنمسي، مجمع شمسي، خزان المائع، المبادل الحر اري (راديثز) 